\title{
Local structures of Ca, Ti, Fe in shergottite fusion glass
}

Tsubasa Tobase $^{1}$, Massimo Nespolo ${ }^{2}$, Akira Yoshiasa ${ }^{3}$, Hidetomo Hongu ${ }^{3}$, Hiroshi Isobe ${ }^{3}$, Maki Okube ${ }^{4}$, Hiroshi Arima ${ }^{4}$, Kazumasa Sugiyama 4

${ }^{1}$ Graduated School Of Science And Technology, Kumamoto University, Kumamoto, Japan, ${ }^{2}$ Université de Lorraine, Nancy, France,

${ }^{3}$ Kumamoto University, Kumamoto, Japan, ${ }^{4}$ Institute for Material and Research, Tohoku university, Sendai, Japan E-mail: 155d9009@st.kumamoto-u.ac.jp

Shergottite is a kind of martian meteorite. Shergottite has the special glass structures which were melted at entering the Earth's atmosphere. The special metamorphism was observed in the local structures of melting glass which were affected by high temperature and rapid cooling at entering the Earth's atmosphere [1]. In order to obtain the information about coordination number, atomic distance and valence state at each ions, we performed local structural analysis of Ca, $\mathrm{Ti}$, and Fe in shergottite by XAFS method. The estimation of environment at entering the Earth's atmosphere and getting out of the Mars were performed by local atomic structural analysis. In this study, the formation environment of melting glass is analyzed by comparison of local structures between those in shergottite and natural impact-related glass.

On the basis of the shape of XANES spectra in shergottite, local structures of Ca in shergottite are almost similar to those in tektite and meteorite fusion glass, although slight difference in XANES spectra is observed in the shape of shoulder feature which is at $7 \mathrm{eV}$ before main peak. This slight difference might come from the chemical composition and coordination environment. The similarities in XANES spectra between shergottite and the other fusion glasses indicate that formation environment of fusion glass in shergottite is almost similar to that in the other meteorite. The main peak position in Fe XANES spectra is related to valence state such as oxidation state of Fe ions, which was influenced by the surrounding oxygen during formation process[2,3]. The main peak position of Fe XANES spectra in shergottite is similar to those in the other fusion glasses, thus fusion glass in shergottite was estimated to be formed under the Earth's atmosphere like the other fusion glasses. On the other hand, local structural information of $\mathrm{Ti}$ in shergottite is different trend to that in Ca and Fe. Since the Ti XANES spectra in shergottite is similar to those in darwin glass whose formation condition is different from the other impact-related glasses and fusion glasses, fusion glass in shergottite might be experienced unique formation process. Shergottite which originated from the Mars contains the fusion glass produced during entering the Earth's atmosphere and glass part influenced during getting out of the Mars. The local structure in fusion glass of unique and different from the other fusion glasses.

Tobase, T., et al. (2016) IOP conference series 712, 012095.

Wang, L., et al., (2013) J. Miner. Petro. Sci., 108, 288-294.

Okudera, H., et al. (2012) J. Miner. Petro. Sci., 107, 127-132.

Keywords: XAFS, Shergottite, Ca Fe Ti local structures 